\title{
Parliamentary punning: Is the Opposition more humorous than the ruling party?
}

\author{
Villy Tsakona \\ Democritus University of Thrace, Greece
}

\begin{abstract}
The present study focuses on the sociopragmatic functions of punning which appears to be the most frequent form of humour Greek politicians produce in parliament. The analysis takes into consideration the institutional particularities of this setting: in parliamentary systems such as the Greek one, competition and disagreement among political parties are more intense than in presidential systems, where party coalitions and collaboration are more frequent. More specifically, I will try to answer the following questions: Are puns the only kind of humour appearing in this setting? Why do Greek parliamentarians resort to punning? How does the use of punning relate to the institutional roles Greek parliamentarians are expected to fulfill, as well as to the institutional particularities of the Greek parliament? The data examined comes from the official parliamentary proceedings, in particular from a noconfidence debate which took place in 2007. The analysis suggests that puns are used as a means of showing off verbal skills: parliamentarians try to project themselves as eloquent orators who are capable of outscoring their adversaries in a highly competitive environment. What is more, via puns parliamentarians criticise and attempt to ideologically delegitimise political decisions and practices. Puns are less often used to bring together parliamentarians and highlight their shared experiences and roles. It therefore seems that punning helps parliamentarians to accomplish their institutional tasks, criticism being (one of) the most significant of them all.
\end{abstract}

Keywords: pun, parliamentary discourse, political humour, criticism. 


\section{Introduction: Rhetorics and humour}

Scholarly interest in the argumentative and persuasive functions of humour goes back to Aristotle's Rhetorics and Cicero's De Oratore. It seems that public speakers observed early on that the audience can be persuaded and amused by the same rhetorical strategies (see Attardo 1994: 20, 26-27). Even nowadays, public speakers often resort to humour to attract and/or divert audience attention and to convince them of the 'rightfulness' of their own views and the 'wrongfulness' of their opponents' ones (Forabosco 2011). Hence, it comes as no surprise that contemporary politicians employ humour, whether in parliament or on other occasions, to enhance their public image and denigrate their opponents.

Focusing on the rhetorical strategies politicians use in parliament, parliamentary discourse analysis investigates the discoursal strategies which are considered typical of the genre and allow parliamentarians achieve their political goals. Among other things, parliamentarians are expected to demonstrate their linguistic and rhetorical skills and to put their opponents in a difficult position. Hence, they often resort to the production of memorable and aggressive soundbites which will attract the attention of the (present and wider) audience and will undermine their adversaries (see Pérez de Ayala 2001: 164; Ilie 2003: 30-31, 2010: 880; and references therein). Humour research has in fact shown that humour plays a significant role in rendering political (and parliamentary) discourse aggressive and memorable, thus drawing the line between the political ingroup and outgroup, while at the same time increasing politicians' popularity in the media (see Dynel 2011; Mueller 2011; Tsakona \& Popa 2011: 6-9; and references therein).

The present study focuses on the Greek parliament, in particular on the puns produced by Greek parliamentarians in debates. In parliamentary systems such as the Greek one, coalition governments are not common and competition among political parties is usually more intense than in presidential systems, where party coalitions are more frequent. In other words, the Greek parliamentary system so far has mostly been a confrontational one where disagreement and hostility are more frequent than collaboration and consensus (Sifianou 2008).

Furthermore, it seems that competitiveness in Greek political discourse often takes the form of verbal duels or exchanges where creative language plays a significant role. Greek politicians employ creative linguistic means, such as repetition, parallelism, alliteration, rhyme, punning, neologisms, hyperbole, metaphor, idioms, and proverbs, to construct political identities and attack the views of their adversaries. Such verbal duels in turn attract media attention and become reportable events, for instance, in newspaper articles reporting on parliamentary issues. It therefore seems that, at least in the Greek context, politicians' ability to use language creatively is directly related to the fulfilment of their institutional role and to their publicity (Archakis \& Tsakona 2008, 2010; Tsakona 2009a, 2009b, 2012a, 2012b; Georgalidou 2011).

Given the above, my aim is to investigate the sociopragmatic functions of punning in Greek parliamentary discourse. More specifically, I will try to answer the following questions:

- Are puns the only kind of humour appearing in this setting?

- For which reasons and purposes do Greek parliamentarians resort to punning?

- How does the use of punning relate, on the one hand, to the institutional roles Greek parliamentarians are expected to fulfil and, on the other, to the institutional particularities of the Greek parliament? 
To this end, section 2 includes a working definition of punning and some main findings from research focusing on its use in everyday and political contexts. Then, in section 3, I offer a brief description of the data under scrutiny and the political context of their production. The qualitative analysis of the data in section 4 reveals that Greek parliamentarians employ punning to denigrate and challenge their opponents, but also to create a friendly atmosphere in the chamber. In the same section, the quantitative analysis of the data shows that puns are primarily used as a weapon of attack by the members of the Opposition in their effort to undermine governmental policies. The benign and friendly use of puns is less common in this setting. Finally, section 5 summarises the conclusions of the study and offers some suggestions for further research.

\section{What is punning and what does it do?}

Formal approaches to puns maintain that puns are "deviant" linguistic uses based on homonymy, paronymy, and polysemy (see among others Attardo 1994: 108-173, 2008: 105106; Dienhart 1999: 108 ff.; Partington 2006: 109-111; Seewoester 2011; and references therein). Here a quite different approach to puns is followed which takes into consideration the context of their appearance: puns are produced when the speaker recycles and reframes either elements which have already occurred earlier in his/her speech, or more or less fixed expressions in wider social circulation. Thus, the speaker aims at giving new meaning to such elements or expressions by recontextualising them. As Carter (2004: 94) aptly remarks, puns are "a kind of verbal schizophrenia", since they point to two different meanings at once. In so doing, puns create either cohesive links between different extracts of a single text or intertextual links between different texts. Their production and interpretation requires evoking the "original" extract or (con)text, so that both meanings are activated, related, and differentiated (see among others Sherzer 1978: 337-340, 1985: 214; Redfern 1984: 157; Dienhart 1999: 123; Norrick 2003: 1345; Carter 2004: 94-100, 128; Partington 2006: 119131).

The following example is illustrative [1]:

Example 1

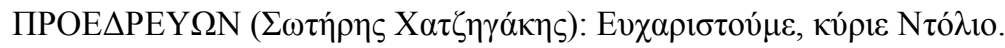

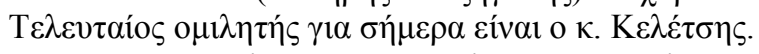

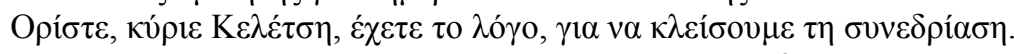

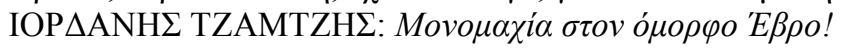

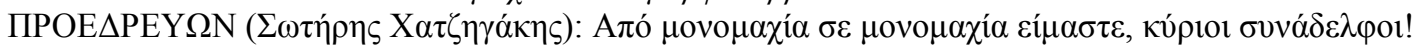

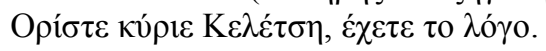

CHAIR (Sotiris Hatzigakis): Thank you, Mr. Dolios [the previous speaker has just terminated his speech].

The final speaker for today is Mr. Keletsis.

Mr. Keletsis, the floor is yours, so as to round up this session.

IORDANIS TZAMTZIS: Duel in beautiful Evros!

CHAIR (Sotiris Hatzigakis): From one duel to another we go, dear colleagues!

Here you are, Mr. Keletsis, the floor is yours.

While the Chair is giving the floor to the next speaker, a parliamentarian from the audience, I. Tzamtzis, intervenes to make a joke by referring to the place both the previous and the next speaker originate in. Both G. Dolios and S. Keletsis are elected in the prefecture of Evros (in the NE part of Greece), so their successive speeches are metaphorically represented as a "duel

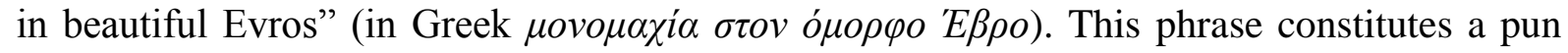


based on popular fixed expressions in Greek such as $\mu о v o \mu \alpha \chi i \alpha \sigma \tau \eta v \dot{\alpha} \gamma \rho \imath \alpha \Delta v \sigma \eta$ "Duel in the

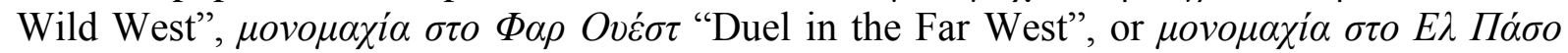
"Duel in El Paso", all evoking spaghetti western films [2]. Hence, the two politicians belonging to opposing parties ( $\mathrm{G}$. Dolios belongs to the then major Opposition party, PASOK, and S. Keletsis to the then ruling party, ND; see section 3) are humorously and metaphorically represented as two cowboys fighting each other to the end.

Research on the sociopragmatic functions of punning in everyday interaction suggests that speakers use puns to interrupt their interlocutors, to shift topic, or to play with language in a more or less competitive and aggressive tone. At the same time, the intertextual links created by puns force interlocutors to evoke meanings and texts which constitute common knowledge, thus reinforcing their shared experiences and values and contributing to their amusement. Those who cannot participate in punning and cannot understand its meanings may find it difficult to communicate with those who can, while the latter are usually characterised as "smart" and "witty" and are positively evaluated (Sherzer 1978: 340-342, 1985; Norrick 1993: 60-69; 2003: 1337-1340, 1345, 1348; Carter 2004: 96-97).

In political contexts, puns appear to be often employed by politicians in public debates to demonstrate their rhetorical skills (Elspass 2002: 90-96). Puns occur frequently in political speeches and aim at distracting audience attention from the important (political or other) messages conveyed, while at the same time highlighting the speakers' verbal skills. In addition, puns are used to attack and denigrate the political adversary (Partington 2006: 112113, 117, 134-142; Tsakona 2009a; Georgalidou 2011).

In what follows, I will provide information on the data examined here and the political parties involved in the debate under scrutiny. I will also show that punning appears to be the most common humorous strategy in this particular setting.

\section{The data of the study}

The data examined comes from the official proceedings of the Greek parliament. In particular, it comes from a no-confidence debate which took place on 2-4 February 2007 (213,249 words). The vote of no-confidence is one of the most important differences between parliamentary and presidential democracies. In the former, the government is accountable to the majority of parliamentarians and can be voted out of office by them, while in the latter, there is no equivalent procedure (this is, for example, the case in the US and in France). Typically, such debates give the Opposition the opportunity to put the government on the stand for what they have or have not achieved, and to point out their vulnerabilities and inadequacies. If party loyalty in the ruling party is weak, a vote of no-confidence may actually result in the downfall of the government and lead to early elections (Gadavanij 2002; Steiner et al. 2004; Tsakona 2011, 2012a, 2012b).

The major Opposition party at that time, the Panhellenic Socialist Movement (henceforth PASOK), accused the then governing conservative party Nea Dimokratia (henceforth ND) of being unable to handle properly and effectively a number of state and parliamentary issues. Admittedly, PASOK must have known in advance that the noconfidence debate would not turn out in their favour; in other words, they would not manage to overthrow the government. Nevertheless, they seized the opportunity to critically attack their opponents and to open a discussion on practically all political issues that mattered at that time. On the other hand, the ruling party was forced to defend their policies and political acts, and to debunk the accusations made by the Opposition. They also accused PASOK that, by launching the no-confidence debate, they tried to impress the public and divert public attention from some intra-party problems PASOK was allegedly facing. 
The two minor Opposition parties at that time, namely the Greek Communist Party (henceforth KKE) and the Coalition of Left Radicals (henceforth SYRIZA), generally did not align with PASOK's argumentation and practice, but tended to frame the whole debate as a confrontational showdown between the two major parties. Hence, they directed their criticism at both of them. In addition, they more or less agreed with the position of the ruling party that PASOK had launched this debate in an effort not to overthrow the government, but to attract media attention and impress the wider audience. At the end, KKE did not participate in the voting at all, while SYRIZA voted against the government.

Obviously, critique is the sine qua non for such debates. Whether belonging to the ruling party or to the Opposition, parliamentarians criticise their opponents for something that was not done as it should have been. The following analysis and discussion will shed some light on how humour contributes to such debates. More specifically, I will concentrate on the sociopragmatic functions of punning, since it seems that, at least in the data examined here, puns are the most common kind of parliamentary humour (see table 1):

Table 1. The forms of parliamentary humour attested in the corpus and their relative frequency

\begin{tabular}{|l|l|l|}
\hline Forms of humour & Tokens & Percentage (\%) \\
\hline Puns & 72 & 52,55 \\
\hline Irony & 51 & 37,22 \\
\hline Narratives & 9 & 6,56 \\
\hline Fictionalisation & 3 & 2,18 \\
\hline Narrative jokes & 2 & 1,45 \\
\hline Total & 137 & 100 \\
\hline
\end{tabular}

More than half of the humorous utterances attested in the corpus involve punning, while one third of them are ironical (Tsakona 2011). Oral narratives, narratives jokes (Archakis \& Tsakona 2011) and fictionalisation (in the sense proposed by Kotthoff 1999) are much less common.

The qualitative and quantitative analysis of the data in the following section will try to shed some light on which sociopragmatic purposes are fulfilled via parliamentary punning as well as on which of these purposes is more frequently attested in this context.

\section{The sociopragmatic functions of parliamentary punning}

The qualitative analysis of the data shows that puns serve three main goals in parliamentary deliberation: they are used (a) to attack and/or denigrate the opponents; (b) to challenge them; and (c) to indicate a friendly and supportive atmosphere in the chamber.

The majority of the puns attested in the corpus fall into the first category: parliamentarians resort to punning to undermine or even ridicule the opposing party and its policies. Example (2) is indicative of such a use:

\section{Example 2}

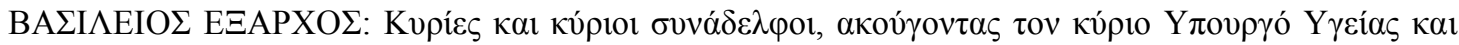

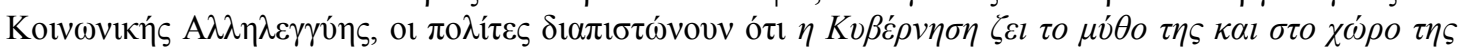
vyeías.

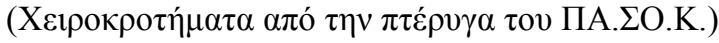

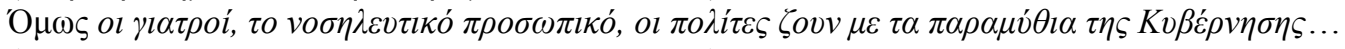

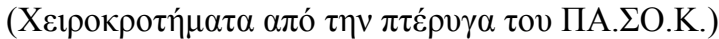

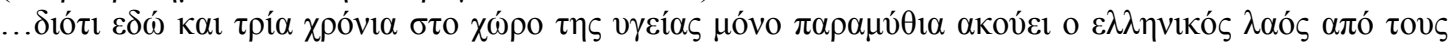

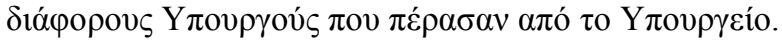

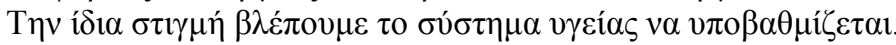


VASILEIOS EXARCHOS: Dear colleagues, while listening to the Minister of Health and Social Solidarity, citizens realise that the government lives their myth in the area of health services as well. (Applause coming from PASOK's wing) But the doctors, the hospital staff, the citizens live with the government's fairy tales... (Applause coming from PASOK's wing)

... because for three years now in the area of health services Greek people only listen to fairy tales told by a series of ministers who served at the ministry.

At the same time we witness the health system deteriorating.

V. Exarchos, a PASOK parliamentarian, is given the floor immediately after the then Minister of Health and Social Solidarity D. Avramopoulos. He produces two successive puns based on a well known advertising slogan used by the Ministry of Tourism when D. Avramopoulos was Minister of Tourism. The original slogan was Live your myth in Greece (in Greek Zí $\sigma \varepsilon \tau o$

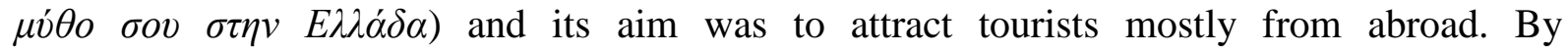
recontextualising the slogan and speaking of the government's myths and fairy tales, V. Exarchos questions the governmental policies on health issues and prepares the ground for the harsh criticism to follow. Both puns denigrate the Minister and are approved by the members of the speaker's party.

Greek parliamentarians also employ punning to challenge their opponents usually by asking them to go to (early) elections as a way to protest against governmental decisions and practices. In example (3), D. Reppas throws down the gauntlet to the government to dare accept the Opposition's proposal for early elections:

Example 3

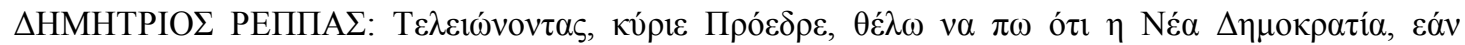

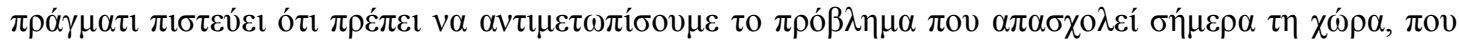

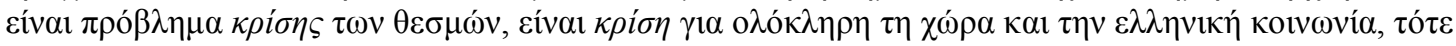

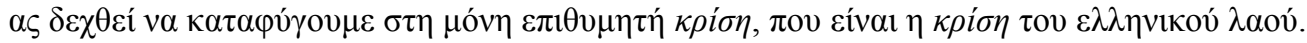

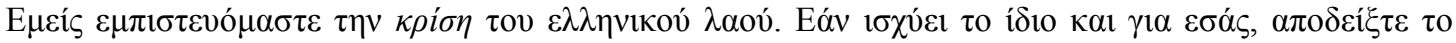

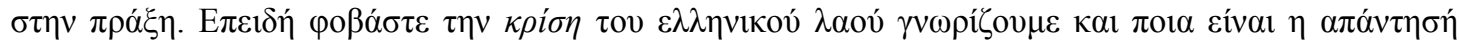

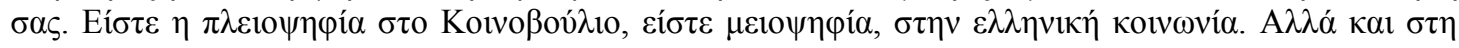

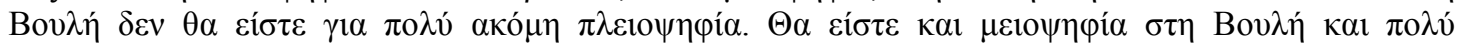

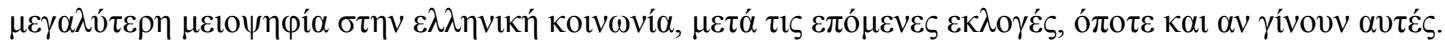

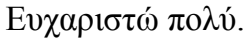

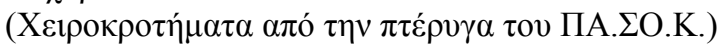

D. REPPAS: Finally, your Honour, I would like to say that if Nea Dimokratia actually believe that we have to deal with the problem the country is facing today, which a problem of institutional crisis, it is a crisis affecting the whole country and Greek society, then they [i.e. the government] should let us resort to the only desirable decision, which is the decision of the Greek people.

We do trust the decision of the Greek people. If the same holds for you [i.e. the members of Nea Dimokratia], prove it in action. Because you are afraid of the decision of the Greek people, we also know what your answer is. You are the majority in parliament, [but] you are a minority in Greek society. However, you are not going to be the majority [in parliament] for long. You will be both minority in parliament and a much smaller minority in Greek society after the next elections, whenever they take place.

Thank you very much [he terminates his speech].

(Applause coming from PASOK's wing)

The pun included in example (3) is untranslatable, hence some explanatory information is required: the English words crisis and decision are here used as translation equivalents for the Greek word $\kappa \rho i \sigma \eta$ [krísi], so the parliamentarian creates a pun by alternating between the two meanings of the word in Greek ("crisis" and "decision"). With this pun D. Reppas challenges the government to go to early elections. His effort is supported by the members of his party. 
The third function attested in the corpus is quite different than the previous two: Greek parliamentarians seem to use puns in a playful manner to create a friendly atmosphere among them, even in competitive sessions such as no-confidence debates. Deputy Chair F. Petsalnikos, before introducing the next speaker from the ruling party, checks whether the rules of order are observed: parliamentarians are not obliged to be in the chamber throughout the whole session, but especially during the discussion of a no-confidence motion, there must be at least one member of the government present to continue with the process. F. Petsalnikos is searching for a member of the government in the chamber and for a moment he does not seem to find any:

\section{Example 4}

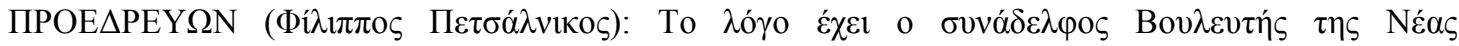

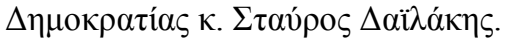

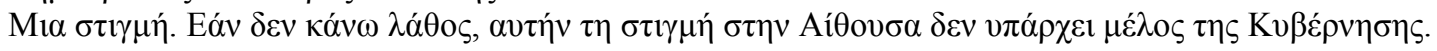
ПРОКОПН

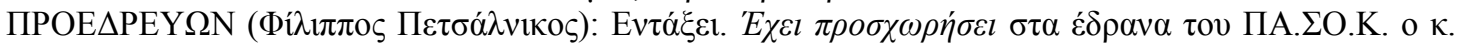

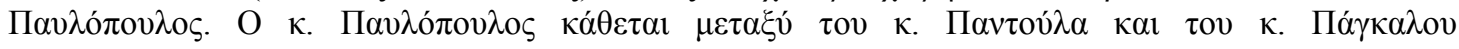

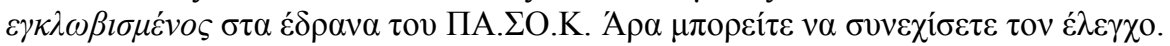

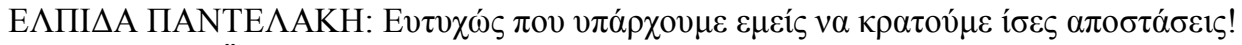

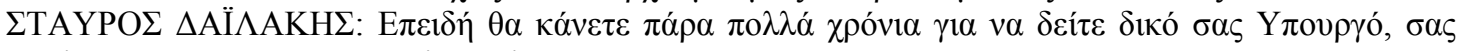

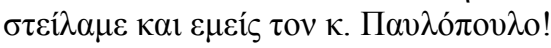

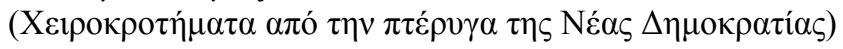

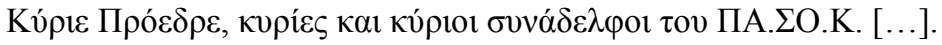

CHAIR (Filippos Petsalnikos): The colleague from Nea Dimokratia Mr. Stavros Dailakis has the floor. Wait a minute. If I am not mistaken, right now there is no member of the government present in the chamber.

PROKOPIS PAVLOPOULOS: I am here, your Honour.

CHAIR (Filippos Petsalnikos): Alright. Mr. Pavlopoulos has joined PASOK. Mr. Pavlopoulos is sitting between Mr. Pantoulas and Mr. Pangalos [two PASOK parliamentarians], trapped among the seats of PASOK. So you [addressing S. Dailakis] can proceed with your talk.

ELPIDA PANTELAKI: It's a good thing we keep equal distance [from both PASOK and ND].

STAVROS DAILAKIS: Since it will be many many years before you [addressing PASOK parliamentarians] see a Minister of your own party, we sent you Mr. Pavlopoulos!

(Applause from ND's wing)

Your Honour, dear colleagues of PASOK [...].

Although Greek parties have their own wings in the parliamentary chamber, sometimes parliamentarians choose to sit to another party's wing to chat with their colleagues, especially when the chamber is not crowded. So, F. Petsalnikos does not at first see any Minister in the seats reserved for the members of the government, but then his attention is drawn to PASOK's wing where the Minister of Internal Affairs P. Pavlopoulos sits between two PASOK parliamentarians. F. Petsalnikos reframes the verb $\pi \rho \sigma \sigma \chi \omega \rho \omega ́$ "join" to refer to P. Pavlopoulos' choice to sit at PASOK's seats instead of the governmental ones. Two senses of the verb join are simultaneously activated: "sit together with someone" and "change political affiliation". Then he playfully represents the Minister as forced to sit there, that is, as held against his own will: the participle $\varepsilon \gamma \kappa \lambda \omega \beta \iota \sigma \mu \varepsilon \dot{v} v \varsigma$ "trapped" is recontextualised to refer to P. Pavlopoulos' deliberate choice of seat. The two puns aim at highlighting solidarity and collegiality among parliamentarians and not at criticising the Minister. Besides, sitting in a different party's wing is not uncommon among them. On the other hand, the Chair himself realises that he should have been more careful when he stopped the procedure to check whether a member of the government was present. At the end, a KKE parliamentarian E. Pantelaki tries to restore the serious mode of the debate, while the next speaker from the 
ruling party, S. Dailakis, before beginning his speech, launches an ironical attack against the Opposition, thus putting an end to the friendly atmosphere.

Another example of this type of punning is extract (1) (in section 2): I. Tzamtzis' pun has a friendly and supportive quality rather than an aggressive one.

The quantitative analysis of the data reveals that the aggressive/denigrating function of puns is by far the prevailing one in this debate (see table 2):

Table 2. The sociopragmatic functions of parliamentary punning in numbers

\begin{tabular}{|l|c|c|}
\hline Functions & Tokens & Percentage (\%) \\
\hline Attack/Denigration & 59 & 81.94 \\
\hline Challenge & 8 & 11.11 \\
\hline Solidarity & 5 & 6.94 \\
\hline Total & 72 & 100 \\
\hline
\end{tabular}

The challenging and supportive functions are clearly less common in this setting. What is more, it seems that the majority of puns come from PASOK, namely the major Opposition party which launched the no-confidence debate (see table 3):

Table 3. Puns per party

\begin{tabular}{|l|c|c|c|c|c|}
\hline Functions & $\begin{array}{l}\text { ND } \\
(165 \text { seats })\end{array}$ & $\begin{array}{l}\text { PASOK } \\
(117 \text { seats })\end{array}$ & $\begin{array}{l}\text { KKE } \\
(12 \text { seats })\end{array}$ & $\begin{array}{l}\text { SYRIZA } \\
(6 \text { seats })\end{array}$ & CHAIR \\
\hline Attack/Denigration & 20 & 37 & 2 & 0 & 0 \\
\hline Challenge & 3 & 5 & 0 & 0 & 0 \\
\hline Solidarity & 1 & 2 & 0 & 0 & 2 \\
\hline Total & $24(33.33 \%)$ & $44(61.11 \%)$ & $2(2.77 \%)$ & $0(0 \%)$ & $2(2.77 \%)$ \\
\hline
\end{tabular}

The institutional role of parliamentarians could account for these results: punning appears to be a powerful humorous weapon of attack in their hands, especially of those who belong to the Opposition and wish to criticise the government and the ruling party in general. It is also used to cast hostility in attractive and memorable terms, thus indicating parliamentarians' effort to demonstrate their verbal and rhetorical skills. At the same time, punning, as a form of humour, seems to bring together people who share experiences and belong to the same group, as well as to underline their common background (whether belonging to the same political party or not). In this light, it is not accidental that parliamentary puns often receive the applause of the audience, especially of that part of the audience which agrees with the views expressed by the punster (see examples 2,3).

\section{Concluding remarks}

Ahl (1988: 21) suggests that "Europeans [...] are trained to admire irony and to disapprove of puns". The Greek parliament seems to be an exception, since puns are the most common form of humour therein. Puns are used as a means of showing off verbal skills: via them parliamentarians demonstrate their (meta)linguistic ability by creating intratextual (as in example 3) or intertextual links (as in examples $1,2,4$ ). Thus, they try to project themselves as eloquent orators who are capable of outscoring their adversaries in a highly competitive environment (see also Tsakona 2009a, 2009b, 2012a, 2012b).

The present analysis brings to the surface the undermining and challenging functions of parliamentary punning. Via puns parliamentarians criticise and attempt to ideologically delegitimise political decisions and practices. Less often are puns used to bring together Open-access journal | EJHR: www.europeanjournalofhumour.org 
parliamentarians and highlight their shared experiences, roles, and identities. Hence, the present findings confirm earlier studies on the exclusive and inclusive functions of humour and its boundary marking potential (see among others Archakis \& Tsakona 2005, 2011; Georgalidou 2011; Mueller 2011). They are also in line with studies suggesting that public speakers resort to humour not only to entertain their audience but also to persuade them (see section 1). Punning as a form of linguistic creativity enables politicians to attract audience attention and to present their positions and arguments in impressive and memorable ways.

Furthermore, although puns are rather strongly related to interlocutors' amusement (especially in everyday encounters), the material analysed here suggests that this is not the case in all communicative settings. Punning helps parliamentarians accomplish their institutional tasks, criticism being (one of) the most significant of them all. In other words, even though in casual interactions among intimates puns may be benign and reinforce the solidarity bonds among them, in an antagonistic context such as a no-confidence parliamentary debate, where conflict talk prevails, puns serve related goals.

It is significant to note here that, in different parliamentary settings, the aggressive dimension of humour may not prevail. For example, in the quantitative analysis of Mueller's (2011) data from the German parliament, there seems to be an equal distribution between aggressive and amusing humour. Such a difference may be related to the fact that in the German parliament collaboration and consensus among parliamentarians in the form of political coalitions are more common than in the Greek one. It therefore seems that puns are multifunctional devices whose function depends on the particularities of the context of their occurrence (Archakis \& Tsakona 2011: 76-77; Popa \& Tsakona 2011: 273-275).

Finally, another aspect of punning (and humour in general) could be worth investigating in parliamentary and other political settings: its spontaneity. In the present debate (as in most Greek parliamentary debates) parliamentarians are expected to use only notes while addressing their colleagues from the podium and not to read aloud from a manuscript. However, parliamentary audiovisual recordings and written proceedings show that Greek parliamentarians usually bend this rule, especially when they are officially enrolled in the list of speakers of a specific session or debate, hence their interventions are not spontaneous. Given the above, it would be interesting to investigate whether parliamentary puns and humour in general is spontaneous (as it is in examples 1 and 4 of the present study) or prepared in advance (as it appears to be in examples 2 and 3), and whether different sociopragmatic functions are fulfilled in each case. In general, more research along these lines is deemed necessary to reveal more and different functions of punning in a variety of political or other settings.

\section{Notes}

* The author would like to thank Argiris Archakis and the members of the audience of the $24^{\text {th }}$ ISHS conference for their insightful remarks on an earlier version of this paper.

[1] The extracts are translated by the author for the purposes of the present study. Punning extracts are marked in italics.

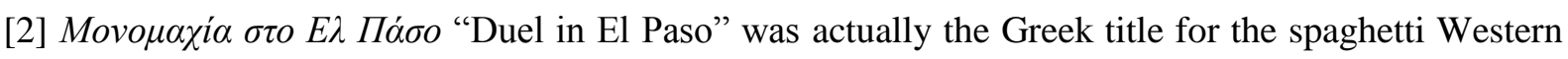
film For a Few Dollars More (Leone 1965

\section{References}

Ahl, F. (1988). 'Ars est caelare artem (Art in puns and anagrams engraved),' in J. Culler (ed.), The Foundation of Letters, Oxford: Blackwell, pp. 17-43. 
Archakis, A. \& Tsakona, V. (2005). 'Analysing conversational data in GTVH terms: A new approach to the issue of identity construction via humour.' Humour: International Journal of Humour Research, 18 (1), pp. 41-68.

Archakis, A. \& Tsakona, V. (2008). 'Analysing parliamentary discourse as reported in Greek newspaper articles,' in P. Politis (ed.), The Discourse of Mass Communication: The Greek Example, Thessaloniki: Institute for Modern Greek Studies, Manolis Triantafyllidis Foundation, pp. 25-49. [in Greek]

Archakis, A. \& Tsakona, V. (2010). "The wolf wakes up inside them, grows werewolf hair and reveals all their bullying": The representation of parliamentary discourse in Greek newspapers.' Journal of Pragmatics, 42 (4), pp. 912-923.

Archakis, A. \& Tsakona, V. (2011). 'Informal talk in formal settings: Humorous narratives in Greek parliamentary debates,' in V. Tsakona \& D. E. Popa (eds.), Studies in Political Humour: In between Political Critique and Public Entertainment, Amsterdam \& Philadelphia: John Benjamins, pp. 61-81.

Attardo, S. (1994). Linguistic Theories of Humour. Berlin \& New York: Mouton de Gruyter.

Attardo, S. (2008). 'A primer for the linguistics of humour,' in V. Raskin (ed.), The Primer of Humour Research, Berlin \& New York: Mouton de Gruyter, pp. 101-155.

Carter, R. (2004). Language and Creativity: The Art of Common Talk. London: Routledge.

Dienhart, J. M. (1999). 'A linguistic look at riddles.' Journal of Pragmatics, 31 (1), pp. 95125.

Dynel, M. (2011). 'Entertaining and enraging: The functions of verbal violence in broadcast political debates,' in V. Tsakona \& D. E. Popa (eds.), Studies in Political Humour: In between Political Critique and Public Entertainment, Amsterdam \& Philadelphia: John Benjamins, pp. 109-133.

Elspass, S. (2002). 'Phraseological units in parliamentary discourse,' in P. A. Chilton \& C. Schäffner (eds.), Politics as Text and Talk. Analytic Approaches to Political Discourse, Amsterdam \& Philadelphia: John Benjamins, pp. 81-110.

Forabosco, G. (2011). 'Notes on humour and persuasion in advertising and legal discourse,' in M. Dynel (ed.), The Pragmatics of Humour across Discourse Domains, Amsterdam \& Philadelphia: John Benjamins, pp. 353-364.

Gadavanij, S. (2002). 'Intertextuality as discourse strategy: The case of no-confidence debates in Thailand,' in D. Nelson (ed.), Leeds Working Papers in Linguistics and Phonetics, 9, pp. 35-55.

Georgalidou, M. (2011). "'Stop caressing the ears of the hooded": Political humour in times of conflict,' in V. Tsakona \& D. E. Popa (eds.), Studies in Political Humour: In between Political Critique and Public Entertainment, Amsterdam \& Philadelphia: John Benjamins, pp. 83-107.

Ilie, C. (2003). 'Histrionic and agonistic features of parliamentary discourse.' Studies in Communication Sciences, 3 (1), pp. 25-53.

Ilie, C. (2010). 'Introduction. Analytical perspectives on parliamentary and extraparliamentary discourses.' Journal of Pragmatics, 42 (4), pp. 879-884.

Kotthoff, H. (1999). 'Coherent keying in conversational humour: Contextualising joint fictionalisation,' in W. Bublitz, U. Lenk \& E. Ventola (eds.), Coherence in Spoken and Written Discourse. How to Create It and How to Describe It. Selected Papers from the International Workshop on Coherence, Augsburg, 24-27 April 1997, Amsterdam \& Philadelphia: John Benjamins, pp. 125-150.

Leone, S. (1965). For a Few Dollars More. USA: United Artists.

Mueller, R. (2011). 'Fun in the German parliament?,' in V. Tsakona \& D. E. Popa (eds.), Studies in Political Humour: In between Political Critique and Public Entertainment, Amsterdam \& Philadelphia: John Benjamins, pp. 33-59. 
Norrick, N. R. (1993). Conversational Joking. Humour in Everyday Talk. Bloomington: Indiana University Press.

Norrick, N. R. (2003). 'Issues in conversational joking.' Journal of Pragmatics, 35 (9), pp. 1333-1359.

Partington, A. (2006). The Linguistics of Laughter. A Corpus-Assisted Study of LaughterTalk. London: Routledge.

Pérez de Ayala, S. (2001). 'FTA and Erskine May: Conflicting needs? Politeness in Question Time.' Journal of Pragmatics, 33 (2), pp. 143-169.

Popa, D. E. \& Tsakona, V. 2011. 'Postscript: A final (?) note on political humour,' in V. Tsakona \& D. E. Popa (eds.), Studies in Political Humour: In between Political Critique and Public Entertainment, Amsterdam \& Philadelphia: John Benjamins, pp. 271-278.

Redfern, W. (1984). Puns. Oxford: Blackwell.

Seewoester, S. (2011). 'The role of syllables and morphemes as mechanisms in humorous pun formation,' in M. Dynel (ed.), The Pragmatics of Humour across Discourse Domains, Amsterdam \& Philadelphia: John Benjamins, pp. 71-104.

Sherzer, J. (1978). 'Oh! That's a pun and I didn't mean it.' Semiotica, 22 (3/4), pp. 335-350.

Sherzer, J. (1985). 'Puns and jokes,' in T. A. van Dijk (ed.), Handbook of Discourse Analysis. Volume 3. Discourse and Dialogue, London: Academic Press, pp. 213-221.

Sifianou, M. (2008). 'Parliamentary discourse and politeness,' in A. Moser, A. BakakouOrfanou, C. Charalambakis \& D. Chila-Markopoulou (eds.), For Language. Festschrift for Professor George Babiniotis by the Department of Linguistics, Athens: Ellinika Grammata, pp. 464-474. [in Greek]

Steiner, J., Bächtiger, A., Spörndli, M., \& Steenberger, M. R. (2004). Deliberative Politics in Action. Analysing Parliamentary Discourse. Cambridge: Cambridge University Press.

Tsakona, V. (2009a). 'Humour and image politics in parliamentary discourse: A Greek case study.' Text \& Talk, 29 (2), pp. 219-237.

Tsakona, V. (2009b). 'Linguistic creativity, secondary orality, and political discourse: The Modern Greek myth of the "eloquent orator".' Journal of Modern Greek Studies, 27 (1), pp. 81-106.

Tsakona, V. (2011). 'Irony beyond criticism: Evidence from Greek parliamentary discourse.' Pragmatics \& Society, 2 (1), pp. 57-86.

Tsakona, V. (2012a). 'Linguistic creativity and institutional design: The case of Greek parliamentary discourse.' Byzantine \& Modern Greek Studies, 36 (1), pp. 91-109.

Tsakona, V. (2012b). "We have become an endless madhouse!": Puns in the Greek parliament,' in Z. Gavriilidou, A. Efthymiou, E. Thomadaki \& P. Kambakis-Vougiouklis (eds.), Selected Papers of the 10th International Conference of Greek Linguistics, Komotini: Democritus University of Thrace, 1170-1178. http://www.icgl.gr/files/greek/114-1170-1178.pdf (accessed 3 February 2013). [in Greek]

Tsakona, V. \& Popa, D. E. (2011). 'Humour in politics and the politics of humour: An introduction,' in V. Tsakona \& D. E. Popa (eds.), Studies in Political Humour: In between Political Critique and Public Entertainment, Amsterdam \& Philadelphia: John Benjamins, pp. 1-30. 